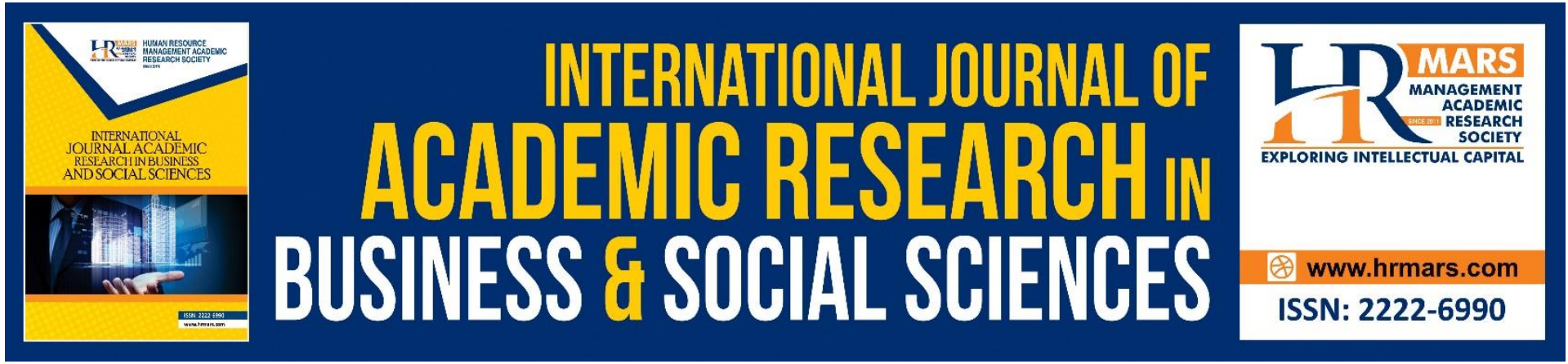

\title{
The Development of Transexual and its Implications on the Muslim Society in Malaysia
}

Wan Nur Izzati Wan Nor Anas, Abdul Karim Ali, Bahiyah Ahmad, Wan Mohd Khairul Firdaus Wan Khairuldin

To Link this Article: http://dx.doi.org/10.6007/IJARBSS/v11-i7/10408

DOI:10.6007/IJARBSS/v11-i7/10408

Received: 05 May 2021, Revised: 07 June 2021, Accepted: 25 June 2021

Published Online: 03 July 2021

In-Text Citation: (Anas et al., 2021)

To Cite this Article: Anas, W. N. I. W. N., Ali, A. K., Ahmad, B., \& Khairuldin, W. M. K. F. W. (2021). The Development of Transexual and its Implications on the Muslim Society in Malaysia. International Journal of Academic Research in Business and Social Sciences, 11(7), 8-14.

Copyright: (c) 2021 The Author(s)

Published by Human Resource Management Academic Research Society (www.hrmars.com)

This article is published under the Creative Commons Attribution (CC BY 4.0) license. Anyone may reproduce, distribute, translate and create derivative works of this article (for both commercial and non-commercial purposes), subject to full attribution to the original publication and authors. The full terms of this license may be seen at: http://creativecommons.org/licences/by/4.0/legalcode

Vol. 11, No. 7, 2021, Pg. 8 - 14

Full Terms \& Conditions of access and use can be found at http://hrmars.com/index.php/pages/detail/publication-ethics 


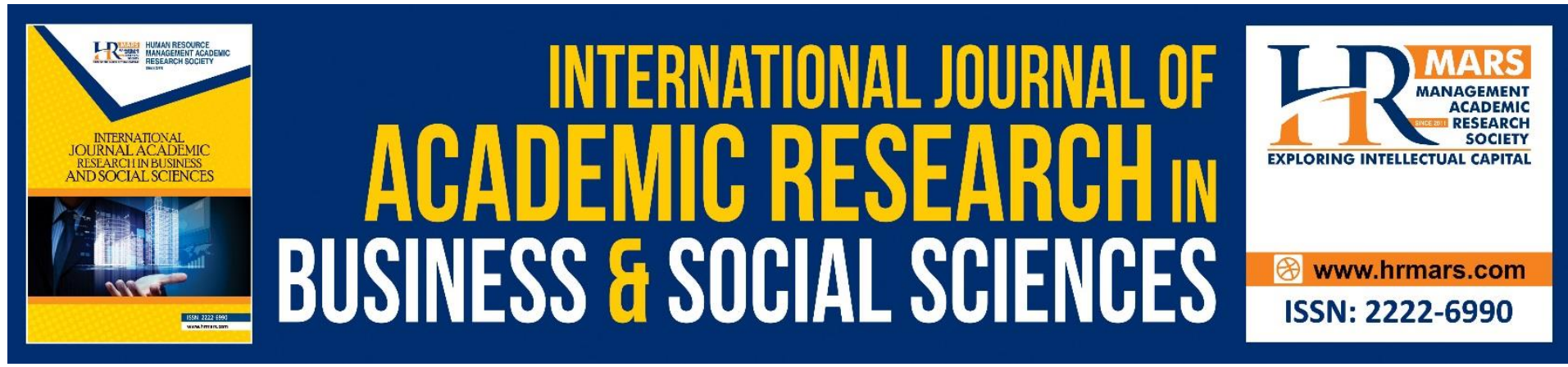

\title{
The Development of Transexual and its Implications on the Muslim Society in Malaysia
}

\author{
Wan Nur Izzati Wan Nor Anas ${ }^{1}$, Abdul Karim Ali ${ }^{1}$, Bahiyah \\ Ahmad $^{1}$, Wan Mohd Khairul Firdaus Wan Khairuldin ${ }^{2}$ \\ ${ }^{1}$ Department of Figh and Usul Fiqh, Academy of Islamic Studies, Universiti Malaya, Kuala \\ Lumpur, ${ }^{2}$ Fakulty of Islamic Contemporary Studies, Universiti Sultan Zainal Abidin, \\ Terengganu \\ Email: abdkarim@um.edu.my
}

\begin{abstract}
Recently, the transsexual problem in Malaysia has become more and more serious. This is a concern because transsexual behavior causes a variety of adverse effects. In fact, transsexual behavior itself is contrary to normal human life. In addition, most of those involved with this transsexual problem is among the youth who are supposed to be the future leaders of the country. Nevertheless, the question is, how did the transsexual problem begin and its development in Malaysia until the statistics on the number of transsexual perpetrators released by the Pink Triangle Foundation in 2013 was 30,000 people in Malaysia. Apart from that, does the development of transsexual problems in Malaysia have particular implications for the Muslim community in Malaysia? Therefore, to answer these questions, this paper has two main objectives. First, to explain the development of transsexual problems in human civilization, including Malaysia. Second, to explain the implications of transsexual problems on the Muslim community in Malaysia. In order to achieve both of these objectives, the documentation method is carried out. A documentation study was conducted to obtain data related to the development of transsexual problems in Malaysia and its implications for the Muslim community in Malaysia. Data were collected using content analysis. The findings of this study found that the development of transsexual symptoms has occurred since the early days of the world until today. This phenomenon also has a negative impact on the Muslim community in Malaysia and challenges the position of the Federal Religion, namely Islam.

Keywords: Transsexsual, Transgender, Development, Implication, Malaysia
\end{abstract}

\section{Introduction}

Transsexual is a person's desire to be of a different gender from his or her original gender. Such a desire is likely to make a person want to change gender through surgery or change body shape and get hormone injections (American Psychiatric Association, 2000). In addition, they also often imitate the opposite sex to themselves in terms of dress, character and speech (Hassan, Yusoff \& Alavi, 1985). 
This transgender problem involves both sexes, namely men and women (Mohamad, 2002). In Malaysia, men who want to be women are known for various titles. Among the titles are 'bapok', 'mak nyah' and 'pondan' (Yik, 2001). Meanwhile, women who want to be men are known as 'pengkid' (Hassan, Yusooff \& Alavi, 1985).

In Malaysia, there are two definitions used in defining transsexuals. Some provide a definition of transsexual as behavior and manner of dressing that is opposite to one's original gender, whether male or female. Meanwhile, there are also groups that use the term transsexual for those who change their original gender to the opposite sex, either male or female (Ramli, 1991).

In general, transsexual is an unhealthy desire and behavior because the desire and behavior are contrary to Islam and normal values as a human being (Mohamad, 2015). The human was created with only two sexes, namely male and female, and this matter will last forever and man cannot change it at all.

Islam prohibits transsexuals or gender reassignment among its believer. This is because transsexual treatment is contrary to Islamic law. In fact, the act of changing the gender is evidence that the individual is not grateful to the gender that Allah s.w.t. has set on him (Sajuri, 2006). Prohibition of changing gender or resembling another gender as in the hadith of the Prophet s.a.w which means (Ibn-Majah, 2002), Meaning: "Indeed, Rasulullah PBUH cursed women who resemble men and men who resemble women.

This hadith clearly shows that resemblance to the opposite sex is a thing that is very much hated by Islam. This is evident with the curse of Rasulullah s.a.w on this group. Their existence as different genders is something that is forbidden by Islam because it is against the human nature that was created at the beginning of life.

\section{Methodology}

The documentation method is used in this paper to obtain a clear picture of the development of transgender problems and its implications on the Muslim community in Malaysia. Classical and contemporary documents are also referenced to collect data to obtain as much information related to transgender.

As a result of this data collection, the data will be analyzed using content analysis methods. This content analysis is used to examine and clarify the interpretations found in the document. Content analysis is a research technique by drawing conclusions, which are made systematically and objectively through documentary data (Krippendorff, 2004; Yusof, 2004. The results of this analysis will explain the implications of transsexual problems on the Muslim community in Malaysia.

\section{Findings}

The findings of this study divide into two. First, the development of transgender problems in human civilization. Second, the implications of transgender on the Malaysian Muslim community. 


\section{Transsexual Development in Human Civilization}

Gender confusion has occurred since time immemorial and can be seen in world civilization (Zafeeruddin, 2004). Transsexual behavior is said to originate from the west. In Indo-America, society there allows men who change gender as women to marry. At the same time, he is naturally a man. The practice of converting the genitals to genitals of different sex to the original genitals already took place before the advent of the 20th century (Calimach, 2000).

However, Islamic history also records that the beginning of transsexuals dates back to the time of the people of Prophet Lut (Hassan, Yusoff \& Alavi, 1985). It is said that the people of Prophet Lut who changed their gender to a different gender with themselves were stuck with the homosexual scene (Mulia, 2009).

Moreover, the development of this transgender culture began in 1952; an individual named Christine Jorgensen created the campaign named 'Awareness of Trans'. The campaign got the attention of the community at that time. As a result of the campaign, the community tried and wanted to know how the lives of transsexuals were. Twenty years later, Sweden recognized gender and became the first country to recognize gender reassignment. After that, in 1991, a documentary called Paris Burning was shown. While in New York in 1999, the day commemorated transgender victims whom anti-transgender groups targeted. Finally, in 2003, the struggle of transgender and transgender people fought for their equal rights by establishing the National Center for Transgender Equality (Townsend, 2012).

Transsexuals have long had a foothold in the race's culture in Malaysia, Malay, Chinese and Indian. This can be seen in the culture of the Malay people who have a soft man dancing like a woman (Rais, 2010). As for the Chinese, some men play female characters in opera movies (Song, 2010). Meanwhile, the Indian community has Hijra, which is a man who cuts his genitals (Jagadish, 2013).

\section{The Implications of Transsexual Problems on the Malaysian Muslim Community}

The problem of transgender people today is increasingly contagious among the Muslim community in Malaysia. It can be seen that most students at the university level fall into transgender individuals (Malib \& Mustafa, 2014). They are no longer shy to dress like women on the campus (Yusof \& Timmiati, 2011). At the same time, they are bound by the dress code on campus.

Although the latest statistics have not been released, there are studies that found that in 2013, the number of lesbian, gay, bisexual or transgender perpetrators was 17300 people (Ariffin, 2018). However, this number does not exclude the actual number of transgender perpetrators. Meanwhile, in 2013 the Pink Triangle Foundation also produced a male transsexual performer statistics, 24,000 Malay race (Sultan, 2013). The number was certainly shocking for society as the number is increasing drastically.

Meanwhile, in 2015, the Global Aids Response Progress Report Malaysia 2015 released statistics on 24,000 transsexual sex workers. Although the number does not refer to Muslims, the figure shows that the transgender problem in Malaysia is at a very alarming level (Ngadiman, 2015). In addition, transgender perpetrators have begun to challenge the Syariah court. This can be seen in the case of men resembling women, such as the case of Muhammad 
Juzaili Bin Mohd Khamis and others against the Negeri Sembilan Government and Others (Mohamad, 2015).

In this case, all three appellants are men. They are Muslims and also have Gender Identity Disorder (GID). They dress like women and behave like women. They also put makeup on their faces. The Negeri Sembilan Religious Enforcement Officer arrested them for the offense of a man behaving like a woman and sentenced under section 66 of the Negeri Sembilan Syariah Criminal Enactment 1992 (Current Law Journal, 1954)

They then applied for judicial review to the Negeri Sembilan High Court against the Syariah Court's decision as they felt it was unfair because they were sentenced under Section 66 of the Sembulan Syariah Criminal Enactment 1992. However, the high court rejected the judicial review application, and they appealed again to the Court of Appeal. The Court of Appeal allowed their appeal and decided to declare section 66 of the EJSNS to be contrary to Articles 5 (1), 8 (1) and (2), 9 (2) and 10 (1) (a) of the Federal Constitution. Therefore, section 66 of the EJSNS is invalid and void.

The outcome of this case had a significant impact on the transgender perpetrator even though the appellant in this case committed a Syariah criminal law offense i.e., men resembled women in dress and conduct. This is because the offense is related to the characteristics of transgender male perpetrators, namely men resembling women. The court's decision leaves room for transgender perpetrators to practice their style as transgender people without fear of being arrested.

There are also some non-governmental organizations that provide support to transgender actors, such as the Pink Triangle. The Pink Triangle was established to provide awareness related to HIV infection to transsexuals. Even so, this body is not awakening transsexual perpetrators to return to the original gender. Pink Triangle also organizes activities for transgender performers. For example, the Beauty Queen Competition Night and the Aidilfitri Night are filled with the presence of transsexual actors. There are studies also found that organizing such activities will form support for transgender perpetrators (Yik, 2002).

Apart from the Pink Triangle, there is also the Mak Nyah Association of the Federal Territory of Kuala Lumpur. Its establishment was established to help transgender actors related to religion, culture and education. The association was established in 1986 under the Ministry of Social Welfare Malaysia. The establishment of this association is also said to strengthen the identity of transsexual actors and make transsexual actors acceptable in the eyes of society (Ramli, 1991).

\section{Conclusion}

In conclusion, transsexual symptoms are highly hated and opposed by Islam as a religion of Rahmatan li al-'alamin. Although there are specific laws about khunsa, the law is only temporary and determined gender. In fact, khunsa does not involve the alteration of the original invention to a different gender.

These transsexual symptoms have also been detected for a long time and have never disappeared to this day. From the time of Prophet Luth AS a.s, this symptom continued to 
grow and hit Europe and then the whole world, including Malaysia. Because of this, many efforts have been made to allow their treatment to take place. This includes the negative impact on the structure of Islam as the Federal Religion in Malaysia.

\section{References}

Al-Qurtubi, M. A. (1999), al-Jami'li Ahkam al-Qur'an. Beirut: Dar al-Basha'ir.

American Psychiatric Association. (2000), Diagnostic and Statistical Manual of Mental Disorders, Washington, DC: American Psychiatric Association.

Benjamin, H. (1999), The Transsexual Phenomenon. Electronic Book. Symposium Publishing. http://www.symposion.com/ijt/benjamin/index.html. Diakses pada 29 April 2018.

Ekins, R. J. M., King, D. (1997). Bending Gender: Contributions to the Emerging Field of Transgender Studies. The International Journal of Transgenderism. 1(1), pp. 1-20.

Hassan, A., Yusoff, F., \& Alavi, K. (1985), "Transeksualiti: Suatu Analisis daripada Perspektif Islam dan Perspektif Keluarga dalam Konteks Kesejahteraan Sosial", Jurnal Perspektif, 5(1), pp. 40.

Calimach, A. (2000). World History of Male Love, "Homosexuals Traditions", The Two Spirit Tradition.

Yusof, F. M., \& Timmiati, S. M. (2011), "Lelaki Lembut:Faktor dan Kesannya Kepada Pembentukan Sahsiah Mahasiswa", Jurnal Teknologi, 56(1), pp.113-150.

Rais, H. (2010). TAPAl: Travels and Guilty Pleasures of a Fermented Malaysian, Kuala Lumpur: ZI Publications Sdn Bhd.

Ibn-Majah. (2002). Sunan Ibn Majah, Beirut : Dar al-Kutub al-Ilmiyah

Mohamad, L. Z. (2002), "Lelaki Transeksual dan Pelacuran Nyah di Malaysia: Sejauhmanakah Pertaliannya". Kertas Kerja Seminar Transeksualiti di Institut Pengajian Tinggi, Century Mahkota Hotel Melaka, 23-25 Julai 2002.

Mohamad, M. (2015), Lesbian, Gay, Biseksual dan Transgender: Perspektif Undang-undang Jenayah Syariah (Lesbian, Gay, Bisexual and Transgender: A Syariah Criminal Law Perspective). Jurnal Undang-Undang dan Masyarakat, 19 (2). pp. 33-39.

Malib, M. A., \& Mustafa, M. S. A. (2014), "Gejala Transeksual: Implikasi Membimbangkan Bagaimana Keprihatinan Kita?", Journal of Business and Social Development, 2 (2), pp.48.

Embong, A. H., Khairuldin, W. M. K. F. W., Yasin, M. F. M., Hassan, A., \& Ibrahim, M. S. (2021, March). Between Reformist and Interpretation: Notes on Hamka's Methodological Strategies as Reformist Mufassir. In First International Conference on Science, Technology, Engineering and Industrial Revolution (ICSTEIR 2020) (pp. 415-422). Atlantis Press.

Majid, S. F., Khairuldin, W. M. K. F., \& Ajmain, M. T. (2019). Fiqh Boycott On LGBT Community: A Review. Perdana: International Journal of Academic Research, 6(2), 35-49.

Anas, W. N. I. W. N., Daud, N., Khairul, W. M., \& Khairuldin, F. W. (2017). The Stance of Alimony or Maintenance for Working Wives within Working Period: An Analysis from the Qualified Jurists (Muftis). International Journal of Academic Research in Business and Social Sciences, 7(4), 2222-6990.

Hassan, S. A., \& Khairuldin, W. M. K. F. W. (2020). Research Design Based on Fatwa Making Process: An Exploratory Study. International Journal of Higher Education 9 (6), 241-246

Townsend, M. (2012). A look back at the history of transgender visibility. Publisher: GLAAD'S Entertainment Media.

Zafeeruddin, M. (2004). Bahaya Homoseks Liwat. Klang: Klang Book Centre. 
Jagadish, P. S. (2013), "Maintstreaming Third Gender Healers: The Changing Perceptions of South Asian Hijras", Vanderbilt Undergraduate Research Journal, Bil. 9.h.1.

Ngadiman, S. (2015). Global Aids Response Progress Report Malaysia 2015. Kuala Lumpur: Kementerian Kesihatan Malaysia. h. 23.

Mulia, S. M. (2009). Understanding LGBT Isssues in Islam Promoting The Appreciation of Human Dignity. 2"d CSBR Sexuality Institue - 11-18 September 2009. Istanbul. Diakses daripada www.asiapasificforum.net/issues/sexual orientation.

Song, H.L. (2010), Celluloid Comrades: Representations of Male Homosexualityin Contemporary Chinese Cinemas, USA: University of Hawai Press.

Nor, S. G. M., Mapjabil, J., Samat, N., \& Jaafar, J. L. S. (2010), "Difusi Ruangan dan Imaginasi Geografi Pelajar Lelaki Transeksual di Universiti Tempatan di Malaysia". Paperwork presented in Persidadangan Kebangsaan ke-3 Pembangunan, Sosial dan Persekitaran.Fakulti Sains Sosial dan Kemanusiaan, Universiti Kebangsaan Malaysia. 20-21 Julai 2010.

The, Y. K. (2002). The Mak Nyahs: Malaysian Male to Female Transsexual. Singapore: Eastern Universities Press.

Ramli, W. A. (1991), Dilema Mak Nyah, Kuala Lumpur, Utusan Publications. Lihat juga dlm. 